\title{
The Promise of Reason: The New Rhetoric after 50 Years
}

Chaim Perelman and Lucie Olbrechts-Tyteca published Le NouvelleRhétorique: Traité de l'Argumentation in 1958, a work that has since come to represent the revival of rhetoric and its reintegration with philosophy in the twentieth century. The influence of this work is felt in rhetoric, philosophy, jurisprudence, communication studies, critical theory, and the newer disciplines of argumentation and informal reasoning.

To commemorate the fiftieth anniversary of the appearance of this work, plans are underway to host an international conference on The New Rhetoric

at the University of Oregon on May 17-20, 2008

Features of the Conference:

- Keynote addresses by major European and American Perelman scholars

- An open call for papers for concurrent sessions

- A symposium of issue-focused position papers, with responses and discussion

- New work on Perelman's life

- Showcase workshops in which graduate and undergraduate students will get responses to their research on the writings of the keynote speakers

\section{MARK YOUR 2008 CALENDAR}

If you wish to be on the mailing list for the call for papers, or have questions about the conference, please contact:

John Gage

Center for Writing, Speaking, and Critical Reasoning

English Department

University of Oregon

Eugene, OR 97403-1286

E-mail: jgage@uoregon.edu 